\title{
Publisher Correction: Accurate autocorrelation modeling substantially improves fMRI reliability
}

Wiktor Olszowy (1) ${ }^{1,2}$, John Aston ${ }^{3}$, Catarina Rua ${ }^{1} \&$ Guy B. Williams ${ }^{1}$

Correction to: Nature Communications https://doi.org/10.1038/s41467-019-09230-w, published online 21 March 2019

The original HTML version of this Article had an incorrect Published online date of 25 December 2019; it should have been 21 March 2019. This has been corrected in the HTML version of the Article. The PDF version was correct from the time of publication.

Published online: 29 March 2019

\begin{abstract}
(c) (i) Open Access This article is licensed under a Creative Commons Attribution 4.0 International License, which permits use, sharing, adaptation, distribution and reproduction in any medium or format, as long as you give appropriate credit to the original author(s) and the source, provide a link to the Creative Commons license, and indicate if changes were made. The images or other third party material in this article are included in the article's Creative Commons license, unless indicated otherwise in a credit line to the material. If material is not included in the article's Creative Commons license and your intended use is not permitted by statutory regulation or exceeds the permitted use, you will need to obtain permission directly from the copyright holder. To view a copy of this license, visit http://creativecommons.org/licenses/by/4.0/.
\end{abstract}

(c) The Author(s) 2019

\footnotetext{
${ }^{1}$ Wolfson Brain Imaging Centre, Department of Clinical Neurosciences, University of Cambridge, CB2 OQQ Cambridge, UK. ${ }^{2}$ Laboratory of Research in Neuroimaging (LREN), Department of Clinical Neurosciences, CHUV, University of Lausanne, 1011 Lausanne, Switzerland. ${ }^{3}$ Statistical Laboratory, Department of Pure Mathematics and Mathematical Statistics, University of Cambridge, CB3 OWB Cambridge, UK. Correspondence and requests for materials should be addressed to W.O. (email: olszowyw@gmail.com)
} 